\title{
ORGANIZATIONAL RESTRUCTURING AS A WAY TO RESOLVE THE CRISIS CAUSED BY COVID 19, IN AGRICULTURAL SECTOR
}

\author{
Snežana Cico $^{1}$, Ljiljana Rajnović2 ${ }^{2}$ Ivan Bošnjak ${ }^{3}$ \\ *Corresponding author E-mail: rajnoviclj@gmail.com
}

A R T I C L E I N F O
Original Article
Received: 23 May 2021
Accepted: 10 September 2021
doi:10.5937/ekoPolj2103611C
UDC 005.591.4+338.431:[616.9
8:578.834]

Keywords:

business crisis, organizational restructuring, pandemic, agricultural sector, digitalization.

JEL: Q10, Q14, G01, G34, K20

\section{A B S T R A C T}

The crisis, as a negative deviation that is serious and can jeopardize the company's business usually doesn't occur suddenly, but gradually in individual areas, accumulating its effects. The crisis caused by the pandemic came suddenly and immediately caused a disruption of economic activities, without the possibility to predict and prevent it. It hit the agricultural sector with great intensity. The analysis of the business entities in agricultural sector in Serbia has shown that these entities suffered great damage and that it is necessary to take restructuring measures as soon as possible, primarily organizational ones. The results of the research showed that the crisis caused by COVID 19, mainly affected the entire long chain of participants in agriculture. Government measures, which included providing financial support and subsidies, are certainly welcome but not sufficient. The authors concluded that it is therefore necessary for companies to implement restructuring measures in order to ensure a speedy recovery.

(C) 2021 EA. All rights reserved.

\section{Introduction}

Restructuring enables the company to overcome the crisis in business, which it enters after a significant decline in economic activity. In this case, the restructuring has its so-called. "regenerative" role. It can also be described as "forced" restructuring or restructuring that prevents bankruptcy, caused by a business crisis that threatens management to lose the control mechanism (Cico, 2018). Organizational restructuring

1 Snežana Cico Ph.D., Severtrans ad Sombor, Filipa Kljajića bb, Sombor, Serbia, Phone: + 381644402057, E - mail: snezanacico@gmail.com, ORCID ID (https://orcid.org/00000003-3356-6767).

2 Ljiljana Rajnović Ph.D., Senior Research Associate, Institute of Agricultural Economics, Belgrade, Volgina 15, Serbia, Phone: + 38163273237, E - mail: rajnoviclj@gmail.com, ORCID ID (https://orcid.org/0000-0002-8209-9088).

3 Ivan Bošnjak, PhD., Lecturer, Academy of Vocational Studies, Šabac, Dobropoljska 5, Serbia, Phone: +381 648116 500, E - mail: ivanbosnjak74@gmail.com, ORCID ID (https:// orcid.org/0000-0002-0202-3850).

http://ea.bg.ac.rs 
is only one of the models of restructuring, but it could be considered as the first, which is commonly applied in the transformation of crisis-affected business. The business crisis should be seen as a state of emergency, which is considered undesirable and which contributes to long-term discontinuity and disruption in business, and not just the current, short-term decline in the company's economic activity. Examining the definition of business crisis in the literature, it can be concluded that there is no single and generally accepted definition. However, some of them indicate that the business crisis in a somewhat narrower sense can be understood as a process in which, unplanned and undesirable, the set basic economic goals of companies are endangered, such as the goal of preserving invested capital, the goal of profit (profitability) and the goal of preserving liquidity and solvency (Malinić, 2020). As such, the crisis is the final stage of an undesirable situation, during which the basic indicators of success develop unfavorably, which calls into question the survival of the company. Such a situation can certainly be observed in the crisis caused by the Covid-19 virus, when the World Health Organization declared (WHO) it a global pandemic, comparing it with natural disasters, with numerous health, social and economic implications (WHO, Coronavirus Disease, COVID-2019, Situation Reports 2020). Due to this phenomenon, many countries have declared a state of emergency, which has even caused the ban on the work of certain economic sectors, including agriculture, all with the aim of reducing and restricting the movement of people.

Agriculture is the primary branch of the economy, present in all economic and political systems that accompany people, in all regions and climatic zones. The activity of agriculture, even in the most developed countries of the world, in addition to the factors and phenomena created by people, is determined by the conditions created by the forces of nature. Agriculture has a dual role: it needs to find a way to produce quality food for the population and at the same time take care of nature while preserving biodiversity. Ecologically sustainable agriculture that uses natural resources wisely is essential for food production and the quality of life of people. For all that, agriculture needs a material basis and permanent acquisition of new knowledge all the time of business.

Serbia is traditionally an agrarian country in which agricultural activity is performed through agricultural farms. According to the official data from the 2012 agricultural census (Agriculture in the Republic of Serbia I 2013; Agriculture in the Republic of Serbia II 2013), there are 631,552 agricultural farms in Serbia that cultivate a total of $3,861,477$ ha of land. Out of the total number of agricultural farms, 628,555 are family farms, and 2,567 are companies, cooperatives, entrepreneurs and farms in private and state or owned by churches and religious communities.

The agribusiness sector is a very important part of the economy in Serbia. This sector produces food for people, significantly affects the environment, has a large share in GDP, which is why the state has a great interest in the good business of economic entities in agriculture.

The development of agriculture also depends on external influences, which are also 
constantly changing. Currently, the crisis caused by the COVID 19 virus pandemic, the most significant external impact on agriculture in Serbia and around the world. The basic question that arises in these conditions is the issue of resolving the consequences of this crisis, which affects the world economy, the economy of each country, specific sectors, including agriculture and all economic entities, the state and the population.

In this paper, the authors tried to show the importance of organizational restructuring of these companies, through empirical research of the results of the work of companies in the field of agriculture, in order to ensure survival and sustainable business. The authors point to changes in the future business of this economic sector, which have to certainly undergo significant changes. The crisis has shown the key role of agriculture as well as the social, health and economic consequences that occur when the free movement of people, goods and services are limited or even completely disabled (European Commission, Brussels, 2020). The author's research also seeks to find an answer to the question: can an adequate model of organizational restructuring be determined for such business entities or does it differ from business entity to entity?

What changes need to be made in these business entities: will it be a reorganization with or without the abolition of organizational units, various programs to reduce the organization, reorganization after status changes and acquisitions, etc. (Rajnović \& Cico, 2019). According to some research (Probst, 2003), it is possible to distinguish three basic categories of organizational restructuring: reorganization, downsizing and mergers and acquisitions, each of which has its own specifics.

\section{Business crisis, causes and possible solutions}

Business entities are exposed to various risks, which are often stated to represent negative deviations from a certain plan. A crisis is a negative deviation that is serious and can jeopardize the very survival of a company (International Finance Corporation, 2010). In the literature, the word crisis is found to be etymological (of Greek origin) and means "judgment" or "decision", i.e. a crucial moment for a decision on further positive or negative development of the situation. The notion of crisis has changed over time. Some authors define the crisis as a situation in which there is a danger of high intensity (Smart \& Thompson \& Vertinsky, 1978), some as the existence of an existential threat to the company (Milisavljević \& Todorović 1991). The crisis is a consequence of poor financial results and management decisions, and resolving the crisis requires adequate and timely decisions.

The analysis of the genesis and characteristics of the crisis, global or regional, emphasizes the importance of the process of economic and financial stabilization. All circumstances and characteristics that change dynamically from day to day form a new business environment (Rajnović \& Cico, 2019).

Observing the impact of the Covid-19 virus pandemic as the cause of the global crisis, it is noticed that this crisis not only affects human health, but also affects the social and economic aspect of life. This crisis is affecting all countries and many business sectors, 
completely changing the way people live. This crisis was caused by an external cause, and it has a great impact on the business of companies. External causes can cause great damage and be extremely dangerous if they are long-term. The consequences of this crisis appear as unfavorable trends and changes in demand, as a cyclical decline, which depends on the movement of economic cycles, especially in times of crisis, which includes the outbreak of the global economic crisis and the creation of a new world order. Although the current crisis could not be predicted, certain predictions related to 2020 indicated a slowdown in the economies of leading countries and a slowdown in global economic flows in general.

\section{Organizational change}

The crisis caused by the pandemic has called into question many things. The impact of COVID-19 is multidisciplinary, influenced both in the field of medicine and in the social fields, has the impact on the environment, agriculture, transport, tourism, the entire social and global environment. We can say that the crisis caused by the pandemic is a new cause of the crisis, but at the same time it is the initiator of certain other patterns of the crisis, which include: management, the need to change the financial policy, the organization of the company becomes inefficient, unfavorable trends and changes in demand, especially in certain economic sectors, which due to the nature of activities are most affected by the new situation.

A possible measure to overcome the crisis in business is certainly restructuring, primarily organizational, through the division of companies or mergers with parts that have a chance for development, with the elimination of parts that make losses association of smaller family farms to reduce costs. Then it is possible to sell parts of the company in order to reduce losses, and there are financial resources that encourage cash flow in a healthy part of the company. In crisis conditions, companies can be merged with other economic entities, and even key creditors, outsourcing, reorganization of the organizational structure with additional training of a certain number of workers, reduction of hierarchical levels of management, downsizing, reducing the number representative offices, abolition of certain sectors, rationalization of distribution (Rajnović \& Subić \& Zakić, 2016).

Business entities are constantly exposed to influences, either externally or internally, which require certain changes in the company itself, which can be partial, when only certain parts are changed, i.e. functions, or all-encompassing, global (radical) ones that actually represent organizational transformation. They are implemented by changing all elements of the organization: system, structure, process and culture (Cico \& Munikravić, 2017).

The term reorganization is often used as a major discontinuous changes for organizational transformation. Such changes lead to the creation of new models of organizations (network, matrix, virtual, etc.) and are focused on several activities aimed at changing the organizational structure. Such changes include reengineering, downsizing, outsourcing. These are major changes that require changes in a number of 
parameters, large-scale and in the short term (Erić \& Stošić, 2013).

The crisis caused by the corona virus is unique in the modern history of economic trends, and because of that it is burdened with numerous uncertainties. Since there is no previous experience, a this crisis is considered atypical. Many countries have adopted measures called lockdown, which certainly hint at a recession. Unlike the Great Depression of 1929-1933. and the Great Global Recession (2007-2009) caused by a fall in aggregate demand, this shock of the pandemic caused a fall in both aggregate demand and aggregate supply. Demand has been reduced, by reducing all its components: household consumption, economy, investments and capital expenditures of the state. On the aggregate supply side, the reduction is even greater because some companies have drastically reduced their work or suspended it completely (due to quarantine closure) in order to maintain social distance (World Economic Outlook: The Great Lockdown, IMF 2020), and the losses of these companies are significant. For these reasons, organizational changes of companies, which are most affected by the crisis, must be implemented in a short time, because only those who react quickly in these circumstances can ensure the continuation of their business.

\section{Forms of applicable organizational restructuring}

Defining and establishing new company goals that follow changes in the environment and formulating a strategy that follows the newly set goals cannot take place without constant changes in organizational forms (Herber, J., Singh, J.V. and Useem, M. 2000).

The goals for implementing organizational restructuring are to do a company more efficient and effective in its business. The following forms of organizational restructuring are most often applied in practice (Handy, 1995):

Outsourcing - Outsourcing is a form of organization in which the relocation of business outside the organization, where certain activities in the company are performed by other companies. It is only a matter of choosing which activities to entrust to others. Some companies tend to keep jobs from the core business and entrust all side activities to others, somewhere it is the case that companies tend to be a kind of virtual organization in which almost all activities would be outsourced and management would deal with business policy. This allows for a significant reduction in costs, but it is necessary to look at it carefully and take into account the costs that can really be eliminated. Time is essential for the implementation of restructuring, especially in times of crisis, and outsourcing can be implemented quickly and, most importantly, savings are provided in a short period of time.

Downsizing - Downsizing is a change in the size of an organization and a reduction in the number of hierarchical levels. Planned abolition of certain jobs or positions, taking care that the reduction is not in the control sector, which must still be effective.

Reengineering - It is a process that implies major business (strategic) and technical changes. Radical changes and complete redesign of business processes are being made in 
order to improve the company's performance: costs, profitability, revenue, turnover, etc. Reengineering enables the reduction of the number of employees, especially the middle level of management, by introducing automation that is not very complete. The essence of reengineering is to merge more and more jobs into one, looking for new solutions in the work in order to enable that. All this leads to the simplification of doing business.

Network organization - Network organization implies the creation of a network of independent organizations that are physically dislocated but still connected by common affairs and resources. It is conducted either through an internal or external network. The internal network is created by regrouping and redistributing jobs into organizational units that actually take the form of separate companies, separating individual parts into separate units facilitates business and influences the attraction of investments for parts that function better. An external network is created when a company transfers activities from its business to other persons, who have the opportunity to do so more professionally, faster and at lower costs. The company that assigned the activities retains control, and helps other members of the network with technological, IT and resources.

Learning organization - In business management, a learning organization is a company that facilitates the learning of its members and continuously transforms itself. This enables them to remain competitive in the business environment.

Strategic alliances - Alliances are actually forms of connecting different companies into a structure that is adaptable and dynamic, building medium-term and long-term relationships to achieve their goals that share the costs, risks and benefits.

Virtual organization - In this form of organization, there are structures where people are connected by partnership, networking, cooperation. Instead of a formal structure, where people are physically present, these are dislocated cadres who do not even know each other. Virtual organizations use mental and technological constructions to represent certain aspects of the organization that traditional organizations possess physical existence. There are common characteristics of this organization: lack of physical structure, communication-basedness, mobility, hybrid forms, lack of formal boundaries, flexibility and sensitivity (Warner \& Witzel, 2004).

\section{Materials and methods}

Information and data used for research in this paper, which refers to the impact of the crisis caused by COVID 19, on business entities engaged in agricultural sector, were obtained during a detailed interview with 61 respondents, on public data, on financial performance of companies, analysis of legal regulations in Serbia and practical examples.

For the purpose of research on this issue, the authors conducted a survey in which 61 respondents participated, of which 32 family farms in the vicinity of Ruma that cultivate less than 50 ha of arable land and 29 agricultural enterprises in Vojvodina. The research was conducted in the period from March to December 2020.

The analysis of the research showed that the largest number of companies immediately 
applied some measures of organizational restructuring, most often the reduction of the corporation, outsourcing, then the reduction of costs and the reduction of the labor force. These measures have somewhat mitigated the damage caused by the crisis.

Family farms were to a lesser extent in a situation to apply restructuring measures, because they did not have the possibilities for e.g. with the reduction of labor, fuel costs, part of the vegetable goods perished permanently, but some of them diversified their activities to a lesser extent.

To provide objective results, the following methods were used to collect and evaluate relevant information:

- data obtaind during detailed interview and the rest mentioned sources, which show that the observed cases can be taken as a typical case, which indicates the possibilities of resolving the crisis in companies by applying restructuring, and above all, organizational restructuring,

- the comparative method enabled the authors to come to generalizations or new conclusions by comparing the same or similar phenomena or by establishing similarities and differences between them,

- the synthesis method was used in the end, to summarize the conclusions at the global level as well as at the level of Serbia, with recommendations for the implementation of organizational restructuring measures in order to resolve the crisis as soon as possible.

From the analysis of all collected data, it was noticed that there are possibilities for resolving the crisis in the business of companies by applying organizational restructuring measures.

\section{Results and discussion}

The authors looked at the crisis in the business of agricultural sector in Serbia, from the point of view of the latest global crisis, which occurred with the appearance of the COVID 19 virus.

The results of research showed that: 1) the impact of COVID-19 of Serbian agricultural sector was mainly reflected in several aspects as crop production, agricultural products supply, livestock production, farmers' income and employment, economic crop development, agricultural products sales model, leisure agriculture development, and agricultural products trade; 2) The measures of government which included resuming agricultural production and farmers' work by providing financial support and providing subsidies were not all in line with the order of impact, which indicates that moretailored policies should be implemented to mitigate the influence of COVID-19 of Serbian agricultural economy in the future.

To control the rapid spread of COVID-19, cities and countries are gradually locked down, and citizens have been quarantined globally. A series of emergent control 
measures, such as shopping centers lockdowns, transportation control, closure of farmer markets, have been adopted immediately throughout the country during the first two months. These measures definitely have had a tremendous impact on Serbian agricultural. Therefore, empirically investigating the impacts of COVID-19 on Serbian agricultural and exploring the Serbian government's emergency measures to ease these impacts are a prerequisite to the ongoing battle against COVID-19. It can assist policymakers in formulating effective policies but also can provide solution for the prevention similar situation in the future.

Agriculture sector has become financially unsustainable due to measures taken by states due to the outbreak of the COVID 19 virus. The activity is very endangered because it is labor intensive (relies on people as perpetrators) and works with people who work together in the field, prepare agricultural products for sale, perform transport, all of it in a limited space, which is considered insufficient to maintain the prescribed distance between people, in case the capacity of the business space, which is commonly used. Agricultural sector faces the application of distance measures because there is an increased risk of infection in it. Too low demand threatens the financial sustainability of the business (Horcher \& Singh \& Graham, 2020).

The market chain in agriculture is complex, it consists of a long chain of participants which (among others) consists of producers of fertilizers, seeds, pesticides and other inputs for agricultural production, agricultural producers, mechanization, logistics, warehouses / refrigerators, processing industry and only finally retail chains and other outlets selling these goods to consumers. If a problem occurs in any part, the product stops or slows down on its way to the consumer. Stabilizing agricultural production and products supply is an important means of guaranteeing people's livelihood.

Agricultural sector was facing a huge financial instability that has not been recorded in recent history. Based on the results of the author's research, the problems coused by pandemia in agriculture relate to:

- decline in demand due to isolation measures, online work, market closures. All this has caused a negative attitude towards public markets, and the belief of users that there is a high risk of infection, which continues to this day and will continue after the measures are relaxed. The structure of demand has changed, so the segment of the so-called luxury foods have already felt the effects of the corona virus, e.g. expensive alcoholic beverages and top delicacies because in this situation, consumers buy only basic groceries,

- control measures applied when buying agricultural products in supermarkets, shops and markets, wearing protective masks and mandatory keeping distance, with the possibility of filling the capacity of points of sale up to several people,

- $\quad$ increase of certain expenses (purchase of hygienic equipment and application of hygienic measures, installation of barriers in markets),

- lack of public funds to subsidize agricultural sector to the appropriate extent, 
- impossibility for business entities to reduce certain costs, most of the operating costs remained and they do not depend on the quantities of goods produced and sold, because they can not be changed quickly, e.g. fixed costs (Horcher \& Singh \& Graham, 2020). Since these costs for most entities will not be covered by revenues, which makes the situation very difficult for those that are financed exclusively from their own revenues and can lead to bankruptcy,

- $\quad$ spring plowing preparation is the basis of obtaining sufficient food supply and is the priority work in spring. Farmers must start spring plowing in time possible to avoid agricultural income loss. This is not only hurting the welfare of people whose revenue is mostly relying on agriculture, but also affecting the stability of food supply. If the spring plowing is delayed by COVID-19 in 2020, the production will be reduced. According to a survey a lot of seed enterprises have not produce nor sold enough seeds after the outbreak of COVID 19. The crop production materials were difficult to available villages due to the lockdowns. Therefore, the shortage of crop production materials has become one of the main obstacles in agricultural production during the outbreak of coronavirus,

- $\quad$ limited by the movement of people, many agricultural enterprises could not do the necessary work in time during the spring sowing,

- $\quad$ isolation measures have disrupted much of the country's food supply chain. The specific effect was as follows: on the supply side, products were not sold, raw materials could not be procured in sufficient quantities, transport of agricultural products was not adequate, and then supply was reduced; on the demand side, households with uncertain incomes and limited access to supermarkets reshaped their demand by purchasing the most necessary goods and with longer shelf life. The overall market demand for agricultural products has declined compared to regular seasons,

- farmer's income had severely affected by COVID-19 on two major components: wage income and agricultural income. Rural workers could not work from home. The closure of workplaces and the transportation restrictions force farmers to stop working. Due to quarantine and transportation restrictions, farmers' local agricultural activities couldn't continue, and the agricultural products couldn't be sold, which indicated a radical decline in agricultural income for the entire year,

- the crisis has severely affected the sale of vegetable crops as a basic agricultural product for citizens. First, due to the lack of agricultural production materials and transport restrictions, continuous vegetable production has become impossible, and large quantities of vegetables that are ripe and yet to ripen could not be sold normally, especially young vegetables that have a short shelf life, significant quantities of vegetables rotted in the fields. Second, the closure of most catering and processing companies has led to a sharp drop in demand for vegetables and a serious backlog of products. However, in the long run, 
labor shortages and regular production will increase the production costs of the vegetable industry and the withdrawal of some producers, which may pose a potential risk of rising vegetable prices,

- the agricultural products sales model has been updated due to COVID-19. People didn't buy food in public places, which stimulated the development of e-commerce platforms. In the long run, if e-commerce platforms continue to be used, Serbian consumers, especially young people, will continue to purchase food online, and it will gradually become people's consumption habits. But many producers from the village did not have the technical ability or knowledge to sell products online. As a result, many products were not sold. Also, online trade implies higher costs, due to which the income of producers decreased or goods became more expensive,

- a lot of countries have severely restricted the export of agricultural products. Although the WHO has proposed that after the outbreak, there is no reason to take unnecessary measures to interfere in international travel and trade, many countries have nevertheless adopted restrictive measures. Serbia has banned the export of the most important agricultural products,

- a series of restrictive measures in various countries have prolonged the transportation and customs clearance time for exported agricultural products, resulting in an increased risk of default on export contracts. Due to the short shelf life and freshness of agricultural products, these strict regulatory measures have significantly increased the economic losses of those products.

Supply chain of exported agricultural products was blocked due to delays in the resumption of work and restrictions on the movement of personnel. Nowadays, the supply chain for agricultural exports has now little recovered, but it still faces delays in export delivery progress. As a result, agricultural products trade has declined significantly after the COVID-19 outbreak.

Serbian government adopted measures to ease the impacts of COVID-19. Resuming agricultural production and farmers' work is primary at present. Providing financial support is one of the central policies to help enterprises effectively cope with the impact of COVID-19. The specific measures of financial support are as follows:

- Serbia provided credit support. Specific measures included implementing favorable policies such as offering subsidized loans to agricultural sector, deferring loan repayment deadlines, and instructing companies to make full use of these policies, postponed the payment of tax liabilities, gave a certain amount of money non-refundable.

- Supply financing guarantee. Specific measures include playing the role of government-backed financing guarantee to the agricultural industry. 
For agriculture sector and related industries that are affected by COVID-19 and suffer severe losses, the government provided financial help to partially solve the difficulties. These subsidies have reduced the survival pressure and business risks of related enterprises, but amount of subsidies are not enough.

More attention could be paid to compensation to farmers and agricultural enterprises due to their huge income loss resulting from COVID-19. Therefore, the following measures might be considered: increasing subsidies to farmers for agricultural inputs to ensure the procurement of production materials, increasing agricultural financial support funds to the recovery of production, establishing a system for reporting, registering and compensating for agricultural production damage during the epidemic, and timely carrying out the compensation to the farmers to ensure the stability of agricultural production.

Agricultural sector in general has a very important role in the economy of our country and has multiple meanings, enabling a quality life for people, its development affects the safety of people as well as the environment. Even before the outbreak of the virus pandemic, the agriculture sector was burdened with numerous problems as: insufficient number of people working in the fields, especially in the villages, relative age of the agricultural machinery, with the obligation to adapt to EU directives, significant presence of gray economy in sale of agricultural products, excessive fiscal expenditures primarily for excise duties on fuel, the need for digitalization of activities.

Due to the implementation of mandatory measures to maintain distance and people's quarantine, online sales were organized on a small scale, for which many small entrepreneurs did not have the opportunity, and for those who did, the costs were increased, the sales were made through resellers or in the gray zone. All this contributed to the realization of extremely low income, even insufficient to cover fixed costs. Revenues decreased a lot during the ban period, compared to the same period last year.

Many countries, and Serbia, have adopted additional measures to help companies in this sector, which are not enough to address the liquidity of these companies. There is a promise of additional help, which means that companies have the so-called a legitimate expectation that a certain property right can be realized, and a legitimate expectation exists only when the state prescribes the conditions under which that expectation will be realized (Rajnović \& Cico \& Brljak, 2020).

\section{Possible application of organizational changes in entities}

In addition to state aid, businesses need to take appropriate measures to stabilize their financial position and secure their future. Poor business performance of companies in the field of agriculture, indicates the conclusion that it is necessary to restructure the business as soon as possible, which should have started immediately with the outbreak of the pandemic, both organizational, financial and maybe ownership restructuring. These are all processes that last and give results over a long period of time. When we talk about organizational restructuring, it is necessary to apply those measures and organizational forms that give results in a short period of time. 
Since wages, fuel costs and public duties make significant value of the total costs of these companies, it was clear that those costs became high, and that certain changes need to be made:

- Applying downsizing, reducing the number of hierarchical levels of management, transferring decision-making to a lower level of management;

- Relocation of tasks outside the organization, with good planning and budgeting, it is necessary to consider whether certain functions, especially those that make ancillary activities should be entrusted to other companies.

- Creating a consortium of several business entities when applying for certain jobs. By performing the work together, the problem of lack of means of could be overcome, i.e. the impossibility of investing in the renewal of the agricultural machinery, etc. whose average age in Serbia is high. In addition, it strives to meet certain standards regarding environmental protection.

- Automation and digitalization in the field of agriculture was a task that was set before the pandemic, but now it is even more important that there is still a need for less contact, but it is also important to reduce operating costs and security quality of work.

For the purposes of the paper, the authors conducted a survey in which 61 respondents participated, i.e. 32 family farms and 29 companies. The data were collected in the period from March to December 2020, by interviews with representatives of economic entities and other mentioned sources. The analysis of the research showed that the largest number of companies immediately implemented some of the measures of organizational restructuring, most often downsizing the corporation, merging with other related companies to share costs and procuring land maintenance materials, which somewhat mitigated the damage caused by the crisis. Farms most often teamed up with other related companies to share costs and procure land maintenance materials.

\section{Conclusion}

Going through the phases of the life cycle, companies are periodically exposed to various crisis situations. Sometimes it happens that in a long period of time, even centuries, this situation is not caused by the COVID 19 pandemic. The appearance of the virus marked a change in people's entire lives and caused major disruptions in economic activity around the world, which was already burdened by various conflicts. In the new crisis circumstances, the restructuring of companies becomes a necessity, especially organizational transformation or major discontinuous change that leads to the application of some other models and forms of organization. Such changes include reengineering, downsizing, outsourcing, etc. These are major changes that require changes in a larger number of parameters, large volume and in a short period of time.

Some economic activities have been extremely affected by the pandemic, and they have even been banned from doing business for a while, due to measures to combat the spread 
of the virus. Among those activities is the agricultural sector. For these reasons, it is necessary to react quickly and establish new forms and ways of doing work, as a condition for the survival of companies in agribusiness sector. Companies in this sector faced two extremes, they fight for survival in the newly created crisis business conditions, and at the same time they are preparing for future business which must be of better quality, more modern, more sophisticated, which certainly requires significant investments.

Adoption of some measures of restructuring, means the necessity and requirements for changes, in terms of taking into account sustainable development, environment and use of modern, digitized techniques in work, connected and automated multimodal mobility. Being in such circumstances in our country, the economic and professional public has taken a stand and advocates for an orderly business environment, in which, together with the institutions, the causes of the problem will be eliminated and the existing solutions will be improved. The economy has a number of concrete, generally acceptable proposals for solutions that are in the general interest.

\section{Acknowledgement}

Paper is the result of Ljiljana Rajnović research financed by Ministry of Education,

Science and Technological Development of the Republic of Serbia.

\section{Conflict of interests}

The authors declare no conflict of interests.

\section{Reference}

1. Agriculture in the Republic of Serbia I (2013), Agriculture in the Republic of Serbia II (2013), Statistic office of the Republic of Serbia, https://pod2.stat.gov. rs/ObjavljenePublikacije/Popis2012/PP-knjiga1.pdf

2. Cico, S., (2018): Company growth cause and / or consequence of corporate restructuring, Accounting, Journal of Accounting, Auditing and Business Finance, Year LXI No. 1-2, Belgrade p. $220-231$.

3. Cico, S., Munikravić, M., (2017) Periodic financial reporting in the function of business decision-making of companies in restructuring, Accounting, Journal of Accounting, Auditing and Business Finance, Year LXI no.1 Belgrade, p 67-78.

4. Crisis Management - A Handbook for Committees (2010), International Finance Corporation.

5. Erić, D., Stošič, I. (2013) Corporate Restructuring, Institute of Economic Sciences, Belgrade Banking Academy, Belgrade.

6. European Commission, Brussels, 9.12.2020, COM (2020) 789 final, Strategy for Sustainable and Smart Mobility - Driving European Transport for the Future, http://ec.europa.eu/transport/sites/transport/files/legislation/com20200789annex.pdf 
7. Handy, C., (1995) Understanding Organizations $4^{\text {th }}$ edition, London\&New York, Penguin Books.

8. Herber, J., Singh, J.V. and Useem, M. (2000) The Design of New Organization Forms, in "Whorton on Managing Emerging Technologies" Whorton Press.

9. Hörcher, D., Singh, R., \& Graham, D. J. (2020). Social Distancing in Public Transport: Mobilising New Technologies for Demand Management under the COVID-19 Crisis, Transportation letters, London.

10.Informant no. 114 Traffic System of Serbia, (2020) Business Association Srbijatransport, Beograd.

11.Lymbersky, C., (2013) International Turnaround Management Standard, Version 1.1. Hamburg, MLP Management Labaratory Press UG.

12.Malinić, S., (2002) Basics of accounting management, Faculty of Economics, Kragujevac.

13.Milisavljević, M., Todorović, J., (1991) Strategic Management, Faculty of Economics, Belgrade, 58 - 72.

14.Probst, T. (2003). Exploring Employee Outcomes of Organizational Restructuring: A Solomon Four-Group Study, Group \& Organizational Management, 28 (3).

15.Rajnović, Lj., Cico, S., (2019) Reorganization plan prepared in advance as a way to solve the liquidity of the company, Institute of Agricultural Economics, Belgrade.

16.Rajnović, Lj., Subić, J., Zakić, N., (2016) Organizational and financial restructuring of companies in the function of improving the economic environment in the Republic of Serbia, Institute of Agricultural Economics, Belgrade.

17.Rajnović, Lj., Snežana, C., Zoran, B., (2020), Restitution of Agricultural Land in Serbia - Comparative Legal Aspects, Agricultural Economics, Publishers: Scientific Society of Agrarian Economists of the Balkans, Belgrade, Institute of Agricultural Economics, Belgrade, Academy of Economic Sciences, Bucharest, Romania, 1355-1366, doi: 10-5937/ekoPolj2004353R.

18.Rajnovic, Lj., Brljak, Z., Cico, S., (2021) Position of holders of right to return land in the procedure of restitution and lessee of land, Sustainable agriculture and rural development, Publisher: Institute of Agricultural Economics, Belgrade, p. $171-183$.

19.Smart, C., Thompson, W., Vertinsky, I., (1978) Diagnosing Corporate Effectivness and susceptibility to Crises, Journal of Business Administration, Canada, 57 - 96.

20.United Nations, World Economic Situation and Prospects (2020), Retrieved from: https://www.un.org/development/desa/dpad/wp- content/uploads/sites/45/ publication/WESP2020_FullReport_web.pdf

21.Warner, M., Witzel. M., (2004), Managing In Virtual Organizations, Publisher: Thomson Learning, London. 
22.WHO Coronavirus Disease (COVID-2019) Situation Reports; World Health Organazation: Geneva, Switzerland, 2020, https://www.who.int/emergencies/ diseases/novel-coronavirus-2019/situation-reports

23. World Economic Outlook: The GreatLockdown,(2020), IMF retrieved 20.11.2020. from the https://www.imf.org/en/Publications//WEO/Issues/2020/04/14/weoapril-2020

24.Prpic, J., Melton, J., Taiehagh, A., Anderson, R., (2015), MOOCs and crowdsourcing: Massive courses ans massive resources, Retrieved 15.12.2020. https://ssrn.com/abstract=3713518 or http://dx.doi.org/10.2139/ssrn.3713518

25.European Commission: Mobility and Transport, Retrieved 10.12.2020. from http://ec.europa.eu/transport/sites/transport/files/legislation/com20200789 -annex.pdf

26.Millennium Development Goals and Beyond 2015, Retrieved 12.12.2020. from https://www.un.org/millenniumgoals/bkgd.shtml 